Vol. 8, No. 1, 2021

https://doi.org/10.23939/eem2021.01.090

UDC 001; 608.1

JEL Classification Code: $\mathbf{0 3 2}$

T. Kvasha
Ukrainian Institute of Scientific and Technical Expertise and Information, Ukraine,
Head of the department,
E-mail: tkvasha13@ gmail.com.

L. Musina

Ukrainian Institute of Scientific and Technical Expertise and Information, Ukraine

$\mathrm{PhD}$, Section Head

E-mail: musina@ukr.net.

\title{
FORESIGHT AS A TOOL OF PUBLIC ADMINISTRATION IN THE FIELD OF SCIENCE, TECHNOLOGY AND INNOVATION
}

\begin{abstract}
Annotation. Given the growing role of technological foresight as a tool for reconciling visions, goals and ways of STI development in an era of rapid technological change and global challenges, the approach to foresight research to select priorities for science and innovation in Ukraine for 2022-2026 has been improved. It takes into account a wide range of national targets for achieving SDGs by 2030. The developed Methodological recommendations provided a thorough analysis of more than 3.000 potentially acceptable technological and innovative proposals. The approach to setting STI priorities is new for Ukraine and involves a consistent process of selecting the top 30 most acceptable proposals in each of the seven thematic areas through five stages of discussions and evaluations. The result was the formation of a database of technology passports and developments on the experts' proposals, their selection by practitioners, ranking, evaluation in terms of the potential of Ukrainian science and relevance in terms of world science and new technologies using international databases. They are the basis for decisions by the Expert Councils and the HighLevel Working Group on key thematic areas and the preparation of a relevant draft government decision. Despite the conditions of quarantine, for the first time more than 2.500 experts from science, business, state and public organizations took part in the discussions, which is the basis for impartial and public decisionmaking. To strengthen the role of foresight as a tool for public planning and management in the field of STI, it is proposed to develop a STI roadmap as part of a research
\end{abstract}

and innovation strategy for smart specialization (RIS 3) at the national level.

Key words: forecasting of scientific and technological development; expert panels; scientometrics, patent research; priority scientific and technological directions

\section{The problem}

With the rapid technological progress and alarming forecasts of climate and environmental deterioration, the requirements and approaches to technological foresight are changing: on the one hand, the analysis of big digital data of scientometric and patent information allows to assess the scientific and innovative priorities of the country's development for their compliance with global trends, on the other hand, those research areas should respond to societal challenges and affect both competitiveness of production and Sustainable Development Goals (SDGs) achievement by 2030.

Taking into account these tasks, the Ukrainian Institute of Scientific and Technical Expertise and Information (UkrISTEI)) has developed methodological recommendations and is working to identify priority areas for science and innovation in Ukraine for 2022-2026, which are based on technological foresight. Foresight is seen as one of the tools of a unified system of public administration 
in the field of science, technology and innovation (STI), aimed at achieving strategic goals of the country's development by aligning the goals and actions of all key stakeholders.

\section{Relevance of the chosen topic}

Due to the fact that in 2021-2022 the Laws of Ukraine "On priority areas of science and technology" and "On priority areas of innovation" expire, the Plan of Priority Actions of the Government of Ukraine for 2021, approved by the Government Order of March 24, 2021, provides for the formation of a new system of priority areas for science and innovation, focused on achieving the SDGs. According to the relevant Decree of the President of Ukraine dated 30.09.2019 No. 722/2019, the tasks of the SDGs must be taken into account when determining the priority areas of science development.

\section{Analysis of recent research and publications}

Problems of scientific and technological forecasting, the formation of scientific, technological and innovation policies are actively explored by the representatives of the Kyiv School of Science of Science B. A. Malitsky, V. P. Solovyov, O. S. Popovych, I. Yu. Egorov [1, 2, 3]. Works by G. O. Androschuk, O. B. Vasiliev, V. V. Virchenko, A. G Zharinova, O. I. Zhilinskaya, M. Z. Zgurovsky, T. K. Kvasha, T. V. Pisarenko, O. F. Paladchenko, P. M. Tsibulyov, L. I. Fedulova, V. K. Khaustov, B. P. Sidenko, Y. Kharazishvili, V. Denisyuk and others $[4,5,6]$. Foreign and domestic scientists [7, $8,9,10,11,12,13]$ consider various aspects of determining the priority areas of scientific, technical and innovative activities through foresight research, in particular for forecasting the future, planning technological policy, and so on.

UN organizations emphasize the important role of the strategic foresight, which generates insights into the dynamics of change, future challenges and new ideas that serve as input for policy development towards the implementation of the Agenda - 2030 [14; 15, p. 5]. Under the United Nations Technology Facilitation Mechanism, a Global Pilot Program has been launched to support countries in developing their STI roadmaps to achieve SDGs. Foresight is an integral tool for the formation of such STI roadmaps, which involves a public discussion of the vision, goals and objectives, alternative scenarios for the country development with all stakeholders [16, p. 23-24].

\section{Purpose and objectives}

Develop Methodological recommendations for determining the priority areas of scientific and technological development of Ukraine for 20222026 and assessing their compliance with modern world scientific and technological trends using the capabilities of information and communication technologies, in particular, international databases Web of Science, Derwent Innovation and others.

To formulate the basic methodological principles of foresight integration into a single system of public management in the field of STI, aimed at achieving strategic goals of the country's development, including the SDGs, based on aligning the goals and actions of key participants in the process.

\section{Presentation of the main material and the results obtained}

Foresight is an interdisciplinary tool and uses a wide range of methods that reflect its functions: forecasting (forecasting trends), analytical (situation analysis), creative (developing new ideas for the future). It covers various methods: qualitative (expert panels, critical technologies, competitive analysis, etc.), quantitative (web metrics, bibliography and scientometrics, modeling, market forecasting), complex (Delphi, scenario development, road mapping, etc.). Expert surveys are a mandatory part of foresight research.

According to Ukrainian legislation, the priority areas of science and technology development are scientifically, economically and socially justified areas of scientific and technical development for the long term, which are given priority state support to form an effective sector of research and development to ensure competitiveness of production, sustainable development, national security and improving the quality of life.

Priority areas of innovation in Ukraine scientifically and economically sound areas of innovation aimed at ensuring the economic security of the state, creating high-tech competitive environmentally friendly products, providing high quality services and increasing the export potential of the state with effective use of domestic and 


\section{T. Kvasha, L. Musina}

world scientific and technological achievements. For the period 2022-2026, the Ministry of Education and Science (MES) and the Government have decided to develop a single system of priority areas for science and innovation, focused on achieving SDGs.

In accordance with the developed Methodological recommendations, the definition of priority areas of scientific and technological development for 2022-2026 is carried out using the foresight methods, taking into account the European Union approach to selecting the priority areas of research under the Horizon-Europe program, as well as nationally defined SDGs tasks for Ukraine [17]. Foresight research was carried out in seven thematic areas: social sciences, energy, environmental management, information and communication technologies (ICT), life sciences (include two separate areas - medicine, agro-food complex), industry, national security.

Foresight research is carried out in five stages, aimed at a comprehensive and impartial choice of priority areas of scientific and technological development of Ukraine, by conducting two surveys of experts. The submitted expert's proposals should be evaluated both in terms of the possibilities for their implementation by Ukrainian scientists, and of the international competitiveness of the proposals, based on the trends of world science and technology. At the final stage, the Expert Councils consider the selected 30 top technologies. The mentioned 5 stages include:

1. Definition of the scientific community's opinions and vision on the priority areas of scientific and technological research and the possibility of their implementation;

2. Evaluation of proposals of experts-scientists by experts-practitioners to determine the proposals in which business and authorities are interested;

3. Evaluation of proposals of expertsscientists from the point of view of possibilities and available potential of the Ukrainian science to carry out the offered researches;

4. Assessment of the relevance of the proposals of experts-scientists in terms of trends in world science and new technologies;

5. Consideration by the Expert Councils of the results of foresight research, formulating and approving the thematic priority areas of scientific and technological development in each area of research.

The opinion and vision of the scientific community was determined by means of a questionnaire. Based on the questionnaires, technology/research proposal passports were developed, which were then provided to expert practitioners to review and evaluate these proposals.

Assessment of opportunities and potential of Ukrainian science for the implementation of the proposed research was carried out using a database of research and development (DB R\&D) and defended dissertations, which was created in UkrISTEI and is constantly updated in accordance with the Procedure for state registration and accounting of open $\mathrm{R} \& \mathrm{D}$ and dissertations, approved by the Order of the Ministry of Education and Science N 977 of 27.10.2008 (registered in the Ministry of Justice on 06.04.2009 under No. 312/16328). According to this Order, all R\&D performed in scientific institutions, higher education institutions (HEIs), enterprises and organizations of Ukraine, which are fully or partially financed from the state budget, are subject to mandatory state registration and accounting.

The relevance of the proposals of expertsscientists from the point of view of world science and the latest technologies was determined for each proposal separately on the basis of the use of international databases: scientific publications Scopus, Web of Science; patent publications and applications - Derwent Innovation.

For each of the proposed areas of research, a step-by-step analysis was performed with the selection of the following stages for each step [18]:

Step I. a) selecting from the database of Web of Science the publications related to the research area subject.

b) Analysis of a selected array of publications from the Web of Science database and, based on its results, selection of the most promising scientific areas.

Step II. a) Selecting from the Derwent Innovation database the patent publications that correspond to the subject under study.

b) Patent analysis based on a selected array of patents using the patent landscape tool [19], and, based on its results, the selection of world advanced technological directions. 
Step III. Analysis of compliance of the scientific and technological development directions, offered for Ukraine, with modern world technological trends.

For each of the first 4 stages, each proposal is evaluated on the basis of methods - systems analysis (stage 1), pairwise comparison (stage 2), cluster analysis (stages 3,4), which are then reduced to a generalized method of constructing integrated estimates. Based on the generalized evaluation, all proposals are ranked, the first 30 of which are proposed for processing as priority thematic areas.

The Working Group established by the MES' order to determine the priority areas of scientific, scientific-technical and innovative activity consists of seven thematic Expert Councils - a group of top experts consisting of leading specialists of the National Academy of Sciences of Ukraine, national branch academies, leading research organizations, institutions higher education, as well as representatives of business and government.

The Expert Councils consider the proposed top 30 technologies / developments, form clusters from them, formulate their names and approve the project of priority scientific and technological directions. In the absence of consensus among the members of the Expert Councils, an additional survey is conducted using the Delphi method. The Working group considers the thematic priorities selected by all Expert Councils, approves them and submits them to the VES for preparation of a draft government decision.

In 2021, more than 2.500 experts were involved in foresight research.

At the first stage - 1556 representatives of scientific research organizations (SROs), institutions of higher education (HEI), which provided almost 3.000 proposals for new promising areas of scientific and technological development of Ukraine in the seven above-mentioned areas of research.

At the second stage -1062 representatives of large and small industrial enterprises, state, municipal and departmental enterprises, associations, unions, authorities of different levels.

Representatives of all regions of Ukraine took part in the polls, among which the highest activity showed the city of Kyiv and Kharkiv region (Table 1).

407 organizations joined the second stage of the expert survey, most of them from Kyiv, Mykolayiv and Odesa oblasts.

According to the results of the analysis, most proposals were received in the socio-humanitarian sphere (Table 2), the highest marks were received from the medical sphere.

The structure of organizations whose representatives submitted proposals for the draft list of scientific and technological priorities in Ukraine in 2021

\begin{tabular}{|c|l|c|c|c|c|c|c|}
\hline No. & Administrative centers & $\begin{array}{c}\text { Univer- } \\
\text { sities }\end{array}$ & $\begin{array}{c}\text { SRO } \\
\text { academic }\end{array}$ & $\begin{array}{c}\text { SRO } \\
\text { non- } \\
\text { academic }\end{array}$ & $\begin{array}{c}\text { Other SPOs } \\
\text { and HEIs }\end{array}$ & Others & TOTAL \\
\hline 1 & 2 & 3 & 4 & 5 & 6 & 7 & 8 \\
\hline 1 & City of Kyiv & 33 & 112 & 35 & 9 & 6 & $\mathbf{1 9 5}$ \\
\hline 2 & Vinnytsia region & 3 & 0 & 0 & 1 & 0 & $\mathbf{4}$ \\
\hline 3 & Volyn region & 2 & 0 & 0 & 0 & 0 & $\mathbf{2}$ \\
\hline 4 & Dnipropetrovsk region & 13 & 6 & 2 & 1 & 1 & $\mathbf{2 3}$ \\
\hline 5 & Donetsk region & 7 & 1 & 1 & 0 & 0 & $\mathbf{9}$ \\
\hline 6 & Zhytomyr region & 4 & 1 & 0 & 0 & 0 & $\mathbf{5}$ \\
\hline 7 & Transcarpathian region & 0 & 2 & 1 & 0 & 0 & $\mathbf{3}$ \\
\hline 8 & Zaporozhye region & 7 & 1 & 0 & 1 & 0 & $\mathbf{9}$ \\
\hline 9 & Ivano-Frankivsk region & 3 & 0 & 1 & 0 & 1 & $\mathbf{5}$ \\
\hline
\end{tabular}


Continuation of Table 1

\begin{tabular}{|c|l|c|c|c|c|c|c|}
\hline 1 & \multicolumn{1}{|c|}{2} & 3 & 4 & 5 & 6 & 7 & 8 \\
\hline 10 & Kiev region & 1 & 6 & 1 & 0 & 1 & $\mathbf{9}$ \\
\hline 11 & Kirovograd region & 1 & 1 & 0 & 0 & 0 & $\mathbf{2}$ \\
\hline 12 & Luhansk region & 3 & 0 & 0 & 0 & 0 & $\mathbf{3}$ \\
\hline 13 & Lviv region & 8 & 12 & 1 & 0 & 0 & $\mathbf{2 1}$ \\
\hline 14 & Mykolaiv region & 3 & 1 & 1 & 0 & 0 & $\mathbf{5}$ \\
\hline 15 & Odessa region & 15 & 9 & 7 & 0 & 0 & $\mathbf{3 1}$ \\
\hline 16 & Poltava & 4 & 1 & 1 & 0 & 0 & $\mathbf{6}$ \\
\hline 17 & Rivne region & 1 & 1 & 0 & 0 & 0 & $\mathbf{2}$ \\
\hline 18 & Sumy region & 4 & 2 & 0 & 1 & 0 & $\mathbf{7}$ \\
\hline 19 & Ternopil region & 4 & 0 & 0 & 0 & 0 & $\mathbf{4}$ \\
\hline 20 & Kharkiv region & 26 & 28 & 7 & 0 & 0 & $\mathbf{6 1}$ \\
\hline 21 & Kherson region & 2 & 0 & 0 & 0 & 0 & $\mathbf{2}$ \\
\hline 22 & Khmelnytsky region & 5 & 0 & 1 & 0 & 0 & $\mathbf{6}$ \\
\hline 23 & Cherkasy region & 4 & 2 & 0 & 0 & 0 & $\mathbf{6}$ \\
\hline 24 & Chernivtsi region & 3 & 1 & 0 & 0 & 0 & $\mathbf{4}$ \\
\hline 25 & Chernihiv region & $\mathbf{1 5 8}$ & $\mathbf{1 9 0}$ & $\mathbf{6 0}$ & $\mathbf{1 3}$ & $\mathbf{9}$ & $\mathbf{4 3 0}$ \\
\hline & Total & & & & 0 & 0 & \\
\hline
\end{tabular}

Table 2

\section{Characteristics of proposals for determining the priority areas of scientific and technological development in Ukraine in 2021}

\begin{tabular}{|c|l|c|c|c|}
\hline No. & \multicolumn{1}{|c|}{ Name of research area } & Number of proposals & Highest rating & Lowest rating \\
\hline 1 & Energy & 229 & 0,83 & 0,04 \\
\hline 2 & ICT & 231 & 0,85 & 0,001 \\
\hline 3 & Agro-food complex & 317 & 0,86 & 0,18 \\
\hline 4 & Medicine & 470 & 0,97 & 0,15 \\
\hline 5 & Rational use of nature & 329 & 0,84 & 0,14 \\
\hline 6 & Industry & 338 & 0,81 & 0,01 \\
\hline 7 & Social and humanitarian & 654 & 0,73 & 0,09 \\
\hline 8 & National security & 284 & 0,85 & 0,09 \\
\hline
\end{tabular}

Based on the results of the proposals' evaluation as well as discussion of the foresight research results, the Expert Councils identified the most important areas of scientific and technological research for Ukraine.

For example, in the field of ICT, the following areas of research are recognized:

1. Artificial intelligence systems

2. Technological tools and software engineering services.

3. Cyber physical systems, the Internet of Things. Robotics. Computer processing of signals of various nature

4. Information and cyber security.
5. Deep learning, Big Data, neural networks.

6. Information and communication systems and networks.

7. Supercomputer complexes. Modeling and solving complex problems. Cloud computing.

8. Intelligent interactive information-analytical systems.

In the field of "Medicine" there are:

1. Etiology, pathogenesis, treatment, prevention of non-communicable diseases (including precision medicine).

2. Etiology, pathogenesis, treatment, prevention of infectious diseases. 
3. Creation of new medicines and medical devices.

4. New methods and technologies for disease diagnosis.

5. Minimally invasive, high-tech, reconstructive surgery and transplantology.

6. Information technology in medicine.

7. COVID-19 and postpartum syndrome 8 . Biosafety and biological protection.

At the time of writing, the Working Group has not considered the scientific and technological priorities approved by the Expert Councils, so the list is preliminary. The identified priority areas are the basis of budget funding for scientific and technological research, i.e. those areas of research for which public funds will be allocated. In view of this, foresight studies play an important role in public administration.

\section{Conclusions and prospects for further research}

Adoption of the Agenda - 2030 in September 2015 helped strengthen the strategic nature of Technology Foresight and its role in identifying solutions to problems in a wide range of areas covered by the SDGs. Increasingly, foresight is being used as a process to encourage debate between all stakeholders to share a long-term understanding and reach consensus on future policies.

In view of this approach, the Methodological recommendations, developed to identify priority areas for science and innovation in Ukraine for 2022-2026, provided a thorough analysis of more than 3.000 potentially acceptable technological and innovative proposals of Ukrainian experts in seven key thematic areas. They take into account a wide range of national targets for achieving the SDGs by 2030.

The approach to setting STI priorities is new for Ukraine and involves a consistent process of selecting the top 30 most acceptable proposals in each thematic area through five stages of discussions and evaluations. As a result of the adopted approach, a database of technology passports / developments was formed based on the proposals of expert scientists, the proposals were ranked according to the results of evaluation by expert practitioners, evaluated in terms of Ukrainian science potential, as well as relevance in terms of world science and latest technologies.
The developed by UkrISTEI Methodological recommendations for foresight study are aimed at discussing potentially priority technological and innovative proposals for Ukraine with a wide range of stakeholders, including science community, business, public authorities and NGOs.

They are structured in seven thematic areas and cover all SDGs. Due to the quarantine restrictions, caused by the COVID-19 pandemic, discussions were mostly conducted online, but this did not reduce the number of participants. In total, in 2021, more than 2,500 experts were involved in foresight research.

The opinion and vision of the scientific community was determined by means of a questionnaire. Based on the questionnaires, technology/development passports were developed, which were then provided to expert practitioners to review and evaluate these proposals.

Involving a wide range of participants from science, business, government and NGOs in the discussions ensured the public nature of foresight research and reaching a consensus on medium-term priorities for science development and innovation in Ukraine. Due to the quarantine restrictions caused by the COVID-19 pandemic, discussions were mostly conducted online, but this did not reduce the number of participants. In total, in 2021, more than 2.500 experts were involved in the foresight.

At the first stage of the discussion, out of a total of 1.556 participants, 816 represented the academic community, 196 non-academic NGOs and 740 higher education institutions. At the second stage, 1.062 representatives of large and small industrial enterprises of various organizational forms, associations, unions, and authorities of various levels were involved in the discussions. Representatives of the agricultural sector, the medical industry, ICT, security and defense are the most constructive in their cooperation. However, the issue of commercialization of the results of domestic academic research remains problematic. Business experts do not accept all proposals of scientists.

At the same time, there is a request from industry to governments and universities to build infrastructure to support modern digital technologies 


\section{T. Kvasha, L. Musina}

and industries, including Industry4.0 centers, digital hubs, clusters, which requires more active business participation in foresight and proposals to the Government.

Currently, the process of clarifying priorities and finding common ground between scientists and business continues. Based on its results, the thematic Expert Councils and the High-Level Working Group will decide on key thematic areas of science and innovation development for the preparation of a draft government decision.

Ukraine's support for the European Green Course will facilitate the digital and green transition of the economy and industry. This will strengthen the role of foresight and innovative solutions, but will require their wider involvement in the public planning and management process.

The European approach to smart specialization, implemented by the European Commission's Joint Research Center (JRC / EC), provides encouraging results in this direction. Development of research and innovation strategies for smart specialization (RIS 3) [20] aims to integrate priorities and plans for the development of science and innovation in a single system of public management of STI at the national and regional levels. It is proposed to use the JRC / EC recommendations on the development of the STI roadmap as part of the smart specialization strategy of Ukraine at the national level, which is currently being developed by the Ministry of Economic Development, Trade and Agriculture together with other interested authorities. The development of a STI roadmap based on foresight will promote more efficient use of state funds for the development of the STI system and attract business funds for the implementation of its achievements and the development of innovative technologies.

\section{References}

1. Malitskyi, B. A., Popovych, O. S. \& Soloviov, V. P. (2004). Methodical recommendations for conducting forecasting and analytical research within the framework of the State Program for Forecasting Scientific, Technological and Innovative Development of Ukraine. K.: Feniks, 52 p. [in Ukrainian]

2. Popovych, O. S. (2019). Science, technology and innovation policy: the main mechanisms of formation and implementation (the second edition is corrected and supplemented). $K$..:Institute for Research of Scientific and Technical Potential and History of Science. R.:Dobrova NAS of Ukraine, 342. [in Ukrainian]

3. Egorov, I., Popovich, O., Solovyov, V. (2003). "Borrowing strategy" and the development of science. Bulletin of the National Academy of Sciences of Ukraine. No. 5. p. 3-14. [in Ukrainian]

4. Zgurovsky, M.Z, (2016). Foresight and construction of the strategy of socio-economic development of Ukraine on the medium-term (until 2020) and longterm (until 2030) time horizons until 2020) and longterm (until 2030) time horizons. Kyiv: NTUU "KPI named after Igor Sikorsky", Publishing House "Polytechnic". 184 p. [in Ukrainian]

5. Haustov, V.K. (2014). Innovative potential of structural changes in Ukraine. Economics and forecasting. No. 2. P. 85-93. [in Ukrainian]

6. Pysarenko, T. V., Kvasha, T. K., Paladchenko, O. F. et al. Foresight in Ukraine in 2019-2020: the vision of experts in priority areas of science and technology in Ukraine for the implementation of the Sustainable Development Goals: a monograph. [in Ukrainian]

7. Popper, R., Keenan, M., Miles, I., Butter, M., Saintz de la Fuenta, S. (2007). Global foresight outlook 2007. EFMN. 66 c. http://www.inovasyon.org/pdf/ efmn.global.foresight.outlook_Popper.et.al.2007.pdf

8. Ben R., Martin. (2002). Technology foresight in a rapidly globalizing. International Practice in Technology Foresight. Vienna : UNID. P. 14.

9. Denisov, V.T., Avdeeva, E.S. (2014). Foresight as forming of national environment of innovative strategic development. Bulletin of Economic Science of Ukraine. № 3. Pp. 20-23. [in Ukrainian]

10. Denezhnikov, S.S. (2015). Foresight methodology in scientific forecasting of the future. Philosophy of science: traditions and innovations. [in Ukrainian]

11. Kvasha, T. K. (2010). Foresight research in Ukraine. Actual problems of science and technology and innovation policy in the context of the formation of the European scientific space: experience and prospects: Proceedings of the international symposium. Phenix. P 353-357. [in Ukrainian]

12. Panchenko, I. A. (2011). Foresight: methodology of technological forecasting. State and regions. Series: Economics and Business. No. 3. P. 30-35. [in Ukrainian]

13. Hafezi, R, Malekifar, S, Akhavan, A. (2018). Analyzing Iran's science and technology foresight 
Foresight as a tool of public administration in the field of science, technology and innovation

programs: recommendations for further practices. FORESIGHT, Value 20. Issue 3. P. 312-331. DOI: 10.1108/FS-10-2017-0064

14. Strategic foresight for the post-2015 development agenda. Report of the Secretary-General. Commission on Science and Technology for Development Eighteenth Session. Geneva. (2015). E/CN.16/2015/3.

15. Foresight Manual. Empowered Futures for the 2030 Agenda. UNDP Global Centre for Public Service Excellence Singapore, January 2018. P. 5.

16. A Guidebook for the Preparation of STI for SDGs Roadmaps. Draft for Consultation (2019). https://sustainabledevelopment.un.org/tfm.

17. Sustainable Development Goals: Ukraine. (2017). http://www.ua.undp.org/content/ukraine/uk/home/li brary/sustainable-development-report/sustainabledevelopment-goals--2017-basseline-nationalreport.html
18. Musina, L. A., Kvasha, T. K. (2020). Research topics assessment in Ukraine in the context of compliance with global technological trends and achievement of the Sustainable Development Goals. Sustainable development - the XXI century. Discussions 2020: a collective monograph under ed. prof. Khlobystova, E. V. Kyiv, National University "Kyiv-Mohyla Academy". 469. H. 17-27. [in Ukrainian]

19. Androshchuk, H. O., Kvasha, T. K. (2019). Patent landscape as a tool for forecasting world technological trends: arms and military equipment. Science, Technologies, Innovations. No. 4(12). P. 28-40. [in Ukrainian]

20. Guide to Research and Innovation Strategies for Smart Specialisation (RIS 3). (2012). https://ec. europa.eu/regional_policy/sources/docgener/presenta /smart_specialisation/smart_ris3_2012.pdf 